\title{
Availability of suitable land-fast ice and predation as factors limiting ringed seal populations, Phoca hispida, in Svalbard
}

\author{
THOMAS G. SMITH and CHRISTIAN LYDERSEN
}

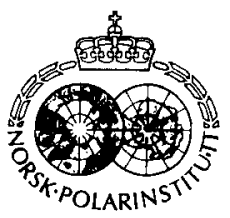

Smith, T. G. \& Lydersen, C. 1991: Availability of suitable land-fast ice and predation as factors limiting ringed seal populations, Phoca hispida, in Svalbard. Pp. 585-594 in Sakshaug, E., Hopkins. C. C. E. \& Oritsland, N. A. (eds.): Proceedings of the Pro Mare Symposium on Polar Marine Ecology, Trondheim, 12-16 May 1990. Polar Research 10(2).

We examined the stability of fast ice areas in western and northern Spitsbergen, the area north of Nordaustlandet, the bays and sounds of Hinlopen Stretet and the large area in the northern part of Storfjorden. NOAA satellite imagery from 1974 and 1988 and NOAA (AVHRR) imagery from 1980-87 were used to determine the dates of freeze-up and break-up. The number of days of fast ice present before the nominal birth date of ringed seal pups were computed for all major bays and fjords. Ice thickness was then computed from these data. Known prime breeding habitat in Svalbard is found in areas near glacier fronts in protected fjords and bays, where densities of birth lairs are $5.46 \mathrm{~km}^{-2}$, corresponding to a ringed seal female density of $2.6 \mathrm{~km}^{-2}$. Most of the ringed seal breeding habitat in Svalbard, however, consists of flat fjord ice where snow accumulation is rarely deep enough to permit birth lair construction. In these areas pups are often born in the open. Based on breathing hole densities, the density of adult females in the flat ice areas in the breeding period was estimated to $0.98 \mathrm{~km}^{-2}$. A preliminary estimate is that approximately 19,500 pups could be born annually in the fast ice of Svalbard. Annual recruitment could be quite variable given the unpredictable nature of the fast ice areas and the high predation mortality on newborn pups. Discrepancies between our calculated ringed seal production and numbers of seals required to feed the large polat bear population in the area signal cause for management concern.

Thomas G. Smith*, Fisheries and Oceans Canada, Arctic Biological Station, 555 St. Pierre Blvd. Ste-Annede-Bellevue, Quebec, Canada H9X 3R4; Christian Lydersen, Department of General Physiology, Division of Biology, University of Oslo, P.O. Box 1051 Blindern, N-0316 Oslo 3, Norway.

\section{Introduction}

Ringed seals, Phoca hispida, are specifically adapted to life in the land-fast sea ice (Smith \& Stirling 1975, 1978; Smith 1987). Not only do they overwinter in the stable, annually formed coastal ice, but they depend on subnivean lairs, dug out of the snow over their breathing holes, in which to give birth and nurture their pups. The hidden complex of lairs is essential for the protection of the small neonate from its principal predators the Arctic fox, Alopex lagopus (Smith 1976), and the polar bear, Ursus maritimus (Stirling \& McEwan 1975; Stirling \& Archibald 1977; Smith 1980). In some areas the lairs are also an important protection from avian predation (Lydersen \& Smith 1989).

* Present address: Pacific Biological Station. Fisheries and Oceans, P.O. Box 100. Nanaimo, B.C., V9R SK6 Canada.
Prevention of hypothermia, caused by the wetting of the pups when they are moved through the water by their mothers during escapes from predators, appears to be one of the primary functions of the sub-snow lairs (Smith et al. 1991).

A combination of stability in annual ice, sufficient snow accumulation for the construction of subnivean lairs, and proximity of feeding areas to the breeding habitat are required for the successful maintenance of a ringed seal population (Hammill \& Smith 1989, 1991).

Comparisons of the fast ice features used by ringed seals in Canada (Hammill \& Smith 1989) and Svalbard (Lydersen \& Gjertz 1986; Lydersen et al. 1990; Lydersen \& Ryg 1991) and a broader examination of the features of sea ice around Svalbard (Vinje 1985) reveal major differences in the suitability of the two regions as ringed seal breeding habitats. In comparison to the vast expanses of prime breeding ice in Canada, good ringed seal breeding habitat appears to be limited 
in Svalbard where the fast ice areas appear to be highly unstable and snow accumulation is very low. From the available data base on fast ice we attempt to give a first approximate description of the quality and quantity of ringed seal breeding habitats in Svalbard.

\section{Materials and methods}

The distribution and extent of fast ice was examined using the National Oceanic and Atmospheric Administration (NOAA) satellite imagery for the years 1974 to 1988 . The data set from 1974 to 1981 is not directly comparable to that of the NOAA ice charts from 1980 to 1987 (NOAA-Advanced Very High Resolution Radiometer (AVHRR)) since the latter gives more detailed information on spacial and temporal fluctuations in fast ice coverage. Nonetheless the complete series from 1974-1988 is considered in order to document extreme variations such as years of completely open water in different parts of Svalbard.

Dates of freeze-up and break-up of ice were noted for five major geographical zones around Svalbard where significant areas of land-fast ice are formed (Fig. 1). These major strata were further subdivided into their fjords and bays which might have had different seasonal ice coverage (Table 1).
Data on average monthly air temperatures for the period 1971-1980 were available for Ny Ålesund and Longyearbyen (Steffensen 1982). More detailed records covering average monthly snow depths measured at the Longyearbyen airport during the period 1975-1988 were obtained from the Norske Meteorlogiske Institutt.

Ice thickness was calculated for the different areas in this study using the equations provided by Vinje (1985) modified from Lebedev (1938) relating ice thickness ( $\mathrm{T}$ in $\mathrm{cm}$ ) to accumulated degree days $(\Sigma \mathrm{Edd})$ below $0^{\circ} \mathrm{C}$ :

$$
\mathrm{T}=15+0.045(\Sigma \mathrm{Edd})
$$

Searches for the sub-snow lairs of ringed seals were conducted using trained dogs which detected the lairs by olfaction (Smith \& Stirling 1975). Kongsfjorden was searched in 1984 (Lydersen \& Gjertz 1986) and again in 1987 and 1988. Notes on type of lair, snow depth at the lair site and predation were taken. Snow depths were measured systematically along several transects in Kongsfjorden in 1987 and 1988 (Fig. 2). Ringed seal birth habitat studies of a similar nature were carried out in Van Mijenfjorden in 1986 (Lydersen et al. 1990), and in Sassen- and Tempelfjorden in 1990 (Lydersen \& Ryg 1991).

We calculated the breeding areas of ringed seals for two types of fast ice habitats, those of glacial fronts and flat fjord ice. On the maps glacial front habitats were identified where glaciers actually

Table 1 . Mean number of days of ice growth before 1 April. and calculated ice thickness from NOAA (AVHRR) satellite images for 8 years from 1980-1987. Number of open-water seasons from 1974-1988.

\begin{tabular}{|c|c|c|c|c|c|}
\hline Area & $\begin{array}{l}\text { Mean number of } \\
\text { ice days }\end{array}$ & $\begin{array}{l}\text { Range } \\
\text { (Days) } \\
\text { Max Min }\end{array}$ & $\mathrm{N}$ & $\begin{array}{l}\text { Calculated } \\
\text { ice thickness } \\
(\mathrm{cm})\end{array}$ & $\begin{array}{l}\text { Seasons } \\
\text { with } \\
\text { no ice }\end{array}$ \\
\hline \multicolumn{6}{|l|}{ 1. Western Spitsbergen } \\
\hline Kongsfjorden & 40 & $-100-8$ & 3 & 38.8 & 7 \\
\hline Forlandsundet & 53 & $97-12$ & 7 & 46.9 & 2 \\
\hline $\begin{array}{l}\text { Isfjorden } \\
\text { Van Mijenfjorden \& }\end{array}$ & 107 & $146-58$ & 7 & 62.0 & 2 \\
\hline Van Keulenfjorden & 105 & $140-34$ & 7 & 61.0 & 2 \\
\hline Hornsund & 38 & $50-23$ & 4 & 22.6 & 6 \\
\hline \multicolumn{6}{|l|}{$\begin{array}{l}\text { 2. Northern Spitsbergen } \\
\text { Woodfjorden \& }\end{array}$} \\
\hline Liefdefjorden & 113 & $143-56$ & 7 & 64.6 & 2 \\
\hline Wijdefjorden & 113 & $143-56$ & 7 & 64.6 & 2 \\
\hline 3. N. Nordaustlandet & 113 & $155-49$ & 7 & 64.6 & 3 \\
\hline 4. Hinlopen and sounds & 103 & $55-28$ & 8 & 59.3 & 2 \\
\hline \multicolumn{6}{|l|}{ 5. Northern Storfjorden } \\
\hline Ginevrabotnen & 57 & $90-14$ & 8 & 31.4 & 5 \\
\hline Freemansundet & 62 & $90-19$ & 7 & 36.9 & 5 \\
\hline
\end{tabular}


descending to the sea were shown. Lines were arbitrarily drawn to indicate the area which would probably be sheltered from currents and therefore allow glacial debris to accumulate and be incorporated into the annual ice at freeze-up.

Area calculations of both these types of habitat were made using a $1 \mathrm{~cm}^{2}$ grid overiay permitting an accuracy of approximately $0.1 \mathrm{~km}^{2}$ in glacier front areas and $0.5 \mathrm{~km}^{2}$ in the flat fjord ice.

\section{Results}

Ice conditions

For ringed seals, sufficient snow depth over breathing holes prior to the pupping season is essential for the construction of birth lairs. We have used 1 April as the average pupping date for ringed seals around Svalbard (Taugbøl 1984). The number of days of stable land fast ice in an area prior to the birth date is the primary factor influencing the quality of ringed seal breeding habitat. Using the NOAA (AVHRR) imagery we examined in detail the number of days of ice prior to pupping for the different sea-ice areas in Svalbard during the period 1980-1987 (Table 1).

In western Spitsbergen, Area 1, the bays in Isfjorden, Van Mijenfjorden and Van Keulenfjorden have the most stable ice conditions with a mean of 107 and 105 ice growth days per year, resulting in thicknesses of 62 and $61 \mathrm{~cm}$ of ice respectively prior to 1 April, over an eightyear period. Kongsfjorden and Hornsund are the least consistent in ice cover with Forlandsundet

Fig. 1. Fast ice areas around Svalbard. Arrows indicate sheltered glacier-front ice areas.

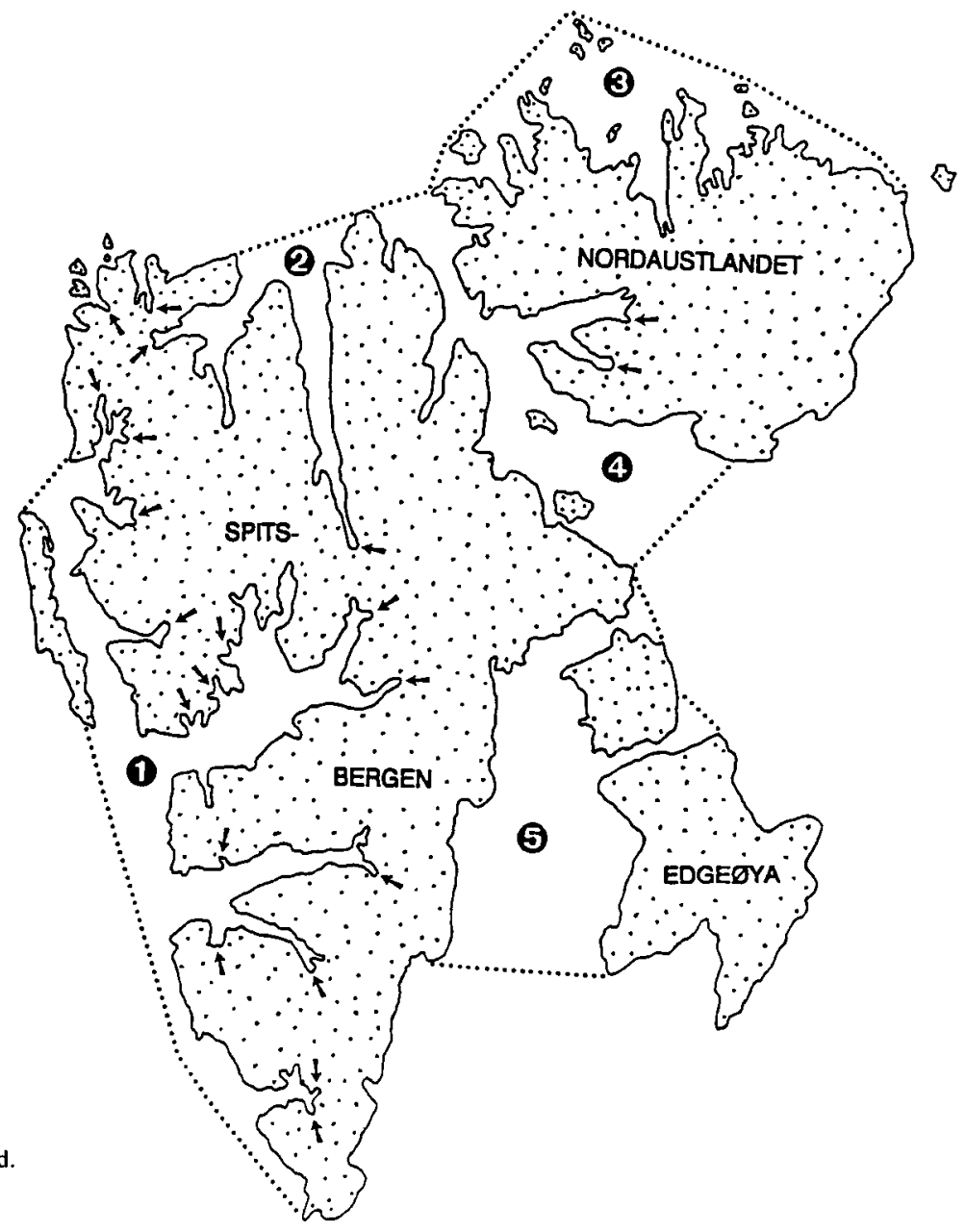




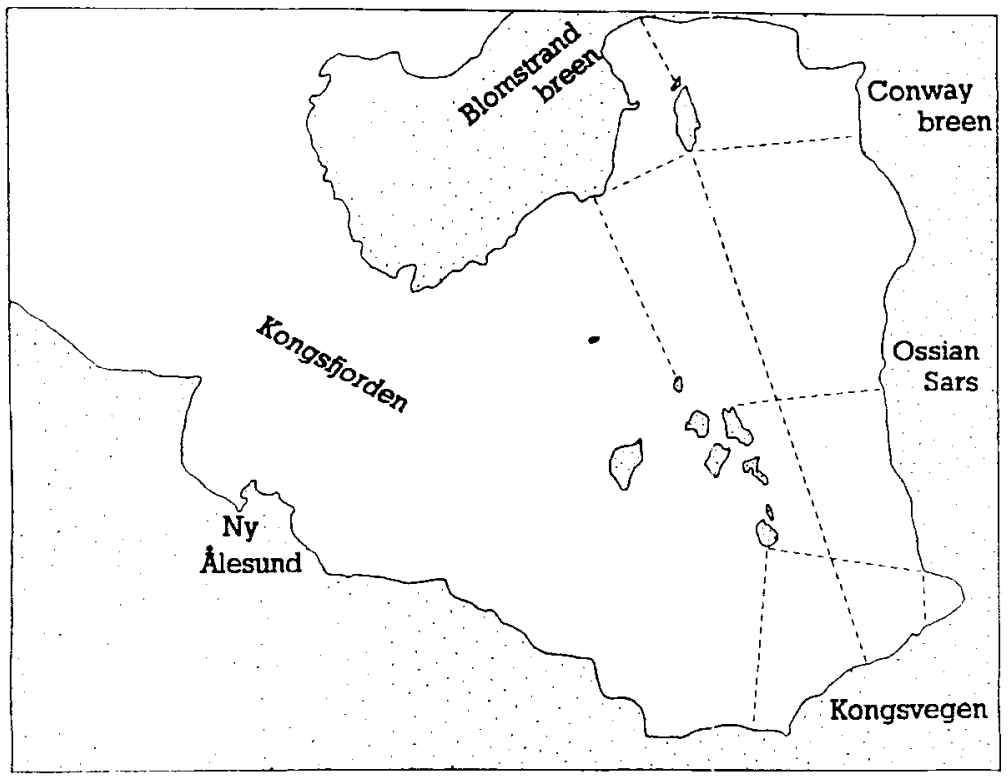

Fig. 2. Transects of systematic snow depth measurements made in Kongsfjorden. Depths werc measured at $200 \mathrm{~m}$ distances along the transects. somewhat more stable. In the eight-year period both Kongsfjorden and Hornsund were considered to be open water during four winters while Forlandsundet remained open for only one winter.

Using all of the NOAA imagery from 1974 to 1987 to examine gross ice stability features, it was found that the highest percentage, $42 \%(6 / 14)$, of open water seasons occurred at Kongsfjorden and Hornsund, while Van Mijenfjorden and Van Keulenfjorden had the most stable conditions without any open-water season at all (Table 2).

In the northern Spitsbergen, Area 2, Woodfjorden, Liefdefjorden and Wijdefjorden are almost identical in ice stability, freezing earlier and breaking up later than the western coast (Table 1). These fjords were open in the winter only once during 14 years in the season of 1982-1983.

Area 3 north of Nordaustlandet consists of a large number of offshore islands which act to anchor the fast ice and are quite stable with a mean of 113 days for ice growth to a thickness of $65 \mathrm{~cm}$ before 1 April. Hinlopen and its associated bays between Spitsbergen and Nordaustlandlet, Area 4 , is almost as stable with 103 days and $59 \mathrm{~cm}$ of ice prior to the pupping season. Open water occurred in 3 of 14 years north of Nordaustlandet and 2 of 14 years in Hinlopen.

Storfjorden with Edgeøya and Barentsøya in
Area 5 is relatively unstable. The area was unfrozen 5-6 winters during 14 years.

\section{Precipitation and snow cover}

The relationship between precipitation, snow depth measured at specific sampling sites for meterological documentation and the actual accumulation of snow cover in ringed seal breeding habitats is not straightforward.

Average precipitation at Ny Ålesund (1971-80) is $385 \mathrm{~mm}$ annually which is significantly greater than the $208 \mathrm{~mm}$ measured at Longyearbyen during 1957-76. In addition to geographic variation between areas in Svalbard, local topographical features also affect precipitation; mountains receive the greatest amount of snow and inner fjords the least (Steffensen 1982).

The relationship between precipitation and actual snow depth is not clear. At Longyearbyen measured average snow depth of $19.2 \mathrm{~cm}$ in March is related to a total average liquid precipitation of $12 \mathrm{~cm}$ from the period beginning in October (Table 3). Simple conversions such as the commonly used factor of 10 to transform liquid precipitation to snow are clearly not applicable in estimating snow cover. Wind force and direction, ice thickness and ice surface topography are all involved in controlling local snow depths. 


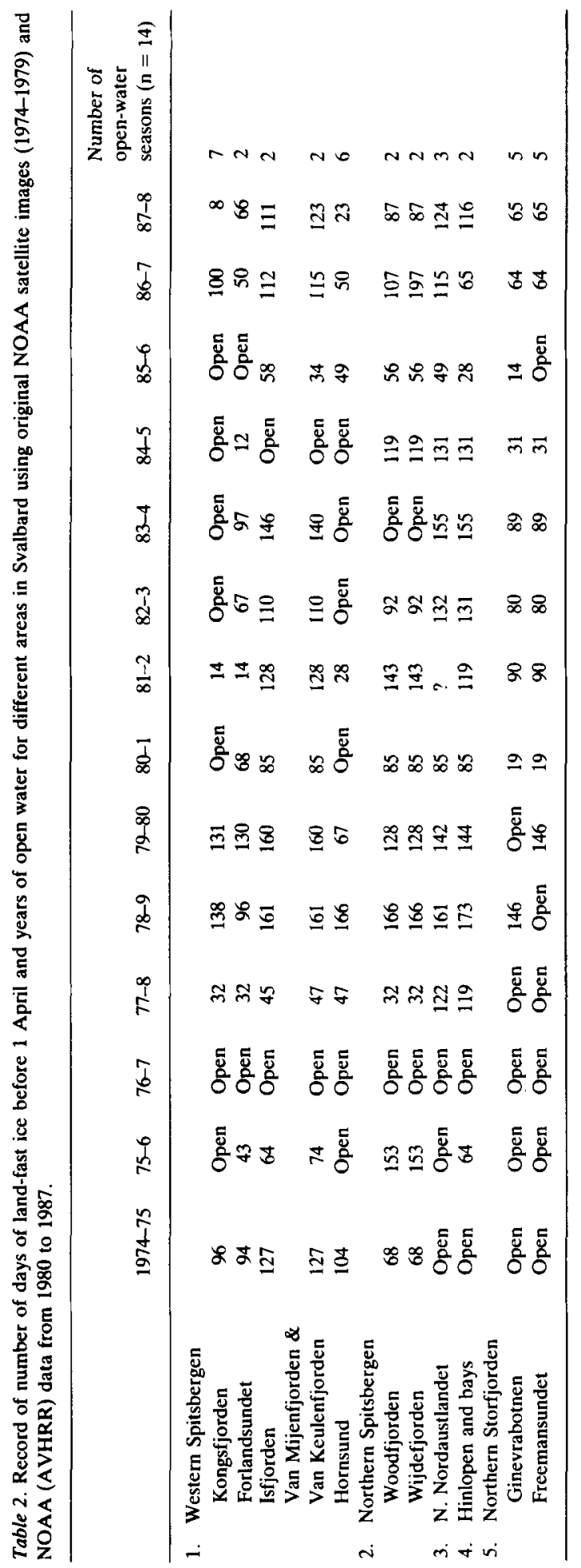


Table 3. Average monthly precipitation (1957 to 1976) at Longyearbyen and average measured snow depth at Longyearbyen airport (1975-1988) for the months of October to March.

\begin{tabular}{lcccccr}
\hline Longyearbyen & Oct & Nov & Dec & Jan & Fcb & Mar \\
\hline Precipitation (cm) & 1.4 & 1.8 & 2.3 & 1.7 & 2.4 & 2.4 \\
Snow depth (cm) & 3.8 & 4.5 & 6.3 & 10.9 & 16.8 & 19.2 \\
\hline
\end{tabular}

\section{Breeding habitats}

In Canada, deformation of large expanses of annual ice into pressure ridges and areas of ice hummocks provide opportunities for snow accumulation to depths sufficient for construction of birth lairs. Only a few areas in Svalbard have been searched for ringed seal subnivean structures. In Kongsfjorden, Area 1, where the most detailed ringed seal studies have been done, snow measurements are available only for a few years. In 1984 when the fjord ice was restricted to an area near the glacier fronts, the average snow depth was reported to be $15 \mathrm{~cm}$ (Fig. 3). In 1987 and 1988, years of unstable and restricted extent of ice, snow depths in the inner parts of Kongsfjorden averaged $25-35 \mathrm{~cm}$. The deepest snow was located near bergy bits and growlers close to the glacier front. It was also there that virtually all ringed seal birth lairs were located (Lydersen \& Gjertz 1986).

Glacier-front habitats are difficult to evaluate because of the deep snow accumulation. The area immediately at the foot of the glacier, extending some $50-100 \mathrm{~m}$ out, is very unstable and probably almost devoid of subnivean structures. Further out where bergy-bits and growlers have frozen into the ice, ringed seals use the considerable accumulation of snow around them for constructing their birth lairs.

Van Mijenfjorden in Area 1 has been surveyed in detail for ringed seal breeding habitat (Lydersen et al. 1990). Being the most stable fast-ice area in western Spitsbergen, the ice surface was free of ridging and almost devoid of glacier ice. Snow cover was low, ranging between $0-30 \mathrm{~cm}$ and most of the seal structures were simple breathing holes. Only two birth lairs were found in the entire survey.

Sassenfjorden and Tempelfjorden, within Isfjorden Area 1, were surveyed as a ringed seal breeding habitat in 1990 (Lydersen \& Ryg 1991). This area was divided into an outer unstable ice area, a mid-stable flat ice area, and an inner stable ice bay ending in a glacier front. Snow cover on the flat ice areas was maximum $20 \mathrm{~cm}$, and almost all structures found also in this study were breathing holes.

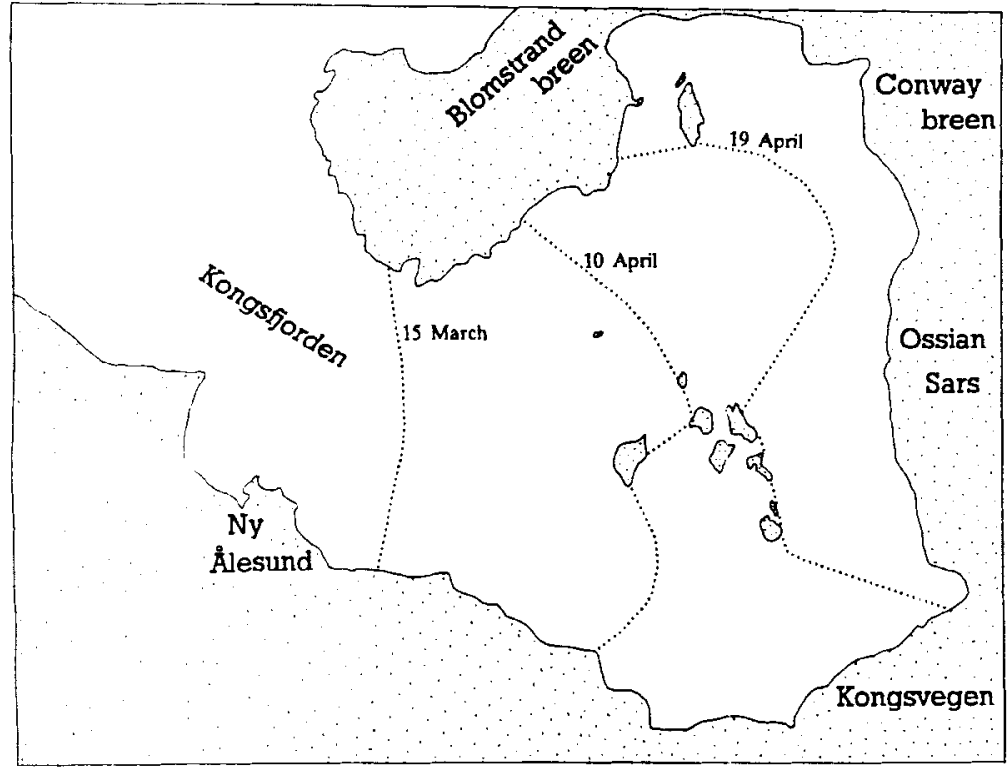

Fig. 3. Extent of fast ice cover and location of the ice edge at Kongsfjorden during the winter of 1984. (From Lydersen \& Gjertz 1986). 
For western Spitsbergen at least, it appears that prime breeding habitat is restricted to glacier fronts. There, snow accumulates to depths of $45-145 \mathrm{~cm}$ (Lydersen \& Gjertz 1986), providing sufficient cover (Smith \& Stirling 1975, 1978) for the construction of birth lairs. The flat ice such as that seen in Van Mijenfjorden provides few areas for lair construction even though the ice platform is very stable.

\section{Extent of breeding habitat}

A preliminary estimate of two categories of breeding habitat, (1) glacier front areas and (2) flat fjord and bay fast ice, was derived from examination of the NOAA imagery and the topographic maps of the Svalbard areas. The surface area of fast ice at glacier fronts in what appeared to be sheltered bays was calculated for the whole region of Svalbard (Fig. 1, Table 4). Similarly the flat fjord and bay fast-ice areas of all the major strata were also compiled.

For western Spitsbergen (Area 1) there is approximately $200 \mathrm{~km}^{2}$ of sheltered glacier front ice and $5580 \mathrm{~km}^{2}$ of fjord and bay fast ice. Northern Spitsbergen (Area 2) contains $40 \mathrm{~km}^{2}$ of glacier front and $2075 \mathrm{~km}^{2}$ of fjord ice. Nordaustlandet (Area 3 ) is all coastal fast ice, an area of approximately $3870 \mathrm{~km}^{2}$. Hinlopen and its associated fjords (Area 4) contains $32 \mathrm{~km}^{2}$ of glacier front ice and $4950 \mathrm{~km}^{2}$ of flat fjord fast ice. The extent of flat fast ice at Edgeøya and Barentsøya (Area 5) is approximately $2825 \mathrm{~km}^{2}$ (Table 4).

\section{Predation and recruitment}

The sub-snow lair serves to hide the seals from foxes, avian predators and polar bears and also to protect the pups from thermal stress after they have been immersed in water during an escape from a predator attack (Taugbøl 1984; Smith et al. 1991). Foxes are very important predators of neonate seals in the birth lairs (Smith 1976). The deep snow of the birth lair site acts as a barrier to the fox entry and gives the female seal time to move her pup to an alternate structure. It appears that in Svalbard the frequent low snow cover caused by ice instability and late seasonal ice formation often results in seals giving birth to their pups in the open. At Kongsfjorden in 1984 Lydersen \& Gjertz (1986) found that foxes had dug into 13 of $28(46 \%)$ birth lairs in which 5 $(18 \%)$ successful kills of pups had been made. This was in a year when the ice platform had repeatedly broken back nearly to the glacier front and the area of the breeding habitat was quite restricted even though the average snow depth at birth lairs near glacier ice was of $89 \pm 15 \mathrm{~cm}$. Even more extreme situations have been documented in Kongsfjorden. In 1987 many pups were born in the open. During the period from 5 to 9 April one of us (TGS) from a vantage point on the small island of Gerdøya witnessed several pups being born in the open. We were able to observe up to four foxes waiting in the nearshore pressure ice for females to drop their pups. In one instance a fox appeared beside the newly born seal within one minute of its birth and frightened the mother who dived down her hole into the sea. The pup was dragged away and killed. Shortly therafter another fox appeared and began to feed on the same pup. In another instance glaucous gulls (Larus hyperboreus) landed beside a newborn pup and would have killed it had they not been disturbed by one of the researchers (Lydersen $\&$ Smith 1989).

Table 4. Areas of sheltered glacier front ice, flat fjord and bay ice and estimated number of breeding ringed seal females for the Svalbard coastal regions.

\begin{tabular}{|c|c|c|c|c|c|}
\hline Area & $\begin{array}{l}\text { Sheltered } \\
\text { glacier front } \\
\text { ice } \mathrm{km}^{2}\end{array}$ & $\begin{array}{l}\text { Number of } \\
\text { breeding females } \\
\left(\times 2.6 / \mathrm{km}^{2}\right)\end{array}$ & $\begin{array}{l}\text { Flat fjord } \\
\text { and bay } \\
\text { ice } \mathrm{km}^{2}\end{array}$ & $\begin{array}{l}\text { Number of } \\
\text { breeding females } \\
\left(\times 0.98 / \mathrm{km}^{2}\right)\end{array}$ & $\begin{array}{l}\text { Total number } \\
\text { of breeding } \\
\text { females }\end{array}$ \\
\hline 1. Western Spitsbergen & 201 & 523 & 5580 & 5468 & 5991 \\
\hline 2. Northern Spitsbergen & 40 & 104 & 2075 & 2034 & 2138 \\
\hline 3. Northern Nordaustlandet & - & - & 3870 & 3793 & 3793 \\
\hline 4. Hinlopen and sounds & 32 & 83 & 4950 & 4851 & 4934 \\
\hline \multirow[t]{2}{*}{ 5. Northern Storfjorden } & - & - & 2825 & 2769 & 2769 \\
\hline & 273 & 710 & 19300 & 18915 & 19625 \\
\hline
\end{tabular}


In Van Mijenfjorden where the ice is much more stable, the low snow cover fails to provide sheiter for pups from predation. In 1986 all six pups born outside lairs in this area were killed by foxes or avian predators, and 10 of 11 mature seals collected in the area appeared to have pupped, but lost their offspring (Lydersen et al. 1987). It should be noted that in 1986 the period of ice prior to 1 April in Van Mijenfjorden was only 34 days compared to an average of 108 days over the period of 12 years.

\section{Discussion}

Much of our knowledge of ringed seal breeding habitat comes from work in the Canadian Arctic archipelago (Smith \& Stirling 1975, 1978; Smith \& Hammill 1981). There large expanses of relatively stable annual ice are anchored between large islands. Prime breeding habitat is formed in snow banks which accumulate near ice deformations such as ice hummocks in large sounds (Smith 1987 ) or pressure ridges running between land masses (Hammill \& Smith 1989).

Fast-ice breeding habitat in Svalbard is neither as extensive nor as stable. Because the islands of Svalbard lie in an area affected by a complex combination of atmospheric and oceanic circulation, large scale interannual variation in sea ice features is common. To date, little is documented of the fast-ice distribution with most of the research having been devoted to the largescale picture of drift, composition, morphology and distribution of the sea-ice fields in the Barents and Norwegian Seas (Lunde 1965; Vinje 196782, 1985).

Sufficient accumulation of snow is the primary factor controlling the construction of birth lairs by ringed seals. This is closely related to date to ice consolidation, snowfall and to ice stability (Hammill \& Smith 1989). In Canada as in Svalbard, the seals require a minimum of 45 to $130 \mathrm{~cm}(\bar{X}=89)$ of snow cover to excavate birth lairs (Lydersen \& Gjertz 1986). Because of ice instability, frequent late consolidation, and lack of deformation of fjord ice in most areas of Svalbard, prime breeding habitat in western Spitsbergen is restricted to glacier fronts in areas where the annual ice is sheltered from strong currents and well anchored by nearby small islets or shoals. There the debris from the glacier frozen into the annual ice provides sites for deep snow accumulation. Kongsfjorden, which has been described in detail as a breeding habitat for ringed seals (Lydersen \& Gjertz 1984, 1986), is one such example. The population of ringed seals there was found to consist of old females $(\bar{X}=14.9$ years) with a high proportion of them $(0.91)$ in reproductive condition (Lydersen \& Gjertz 1987). Since ringed seals are almost certainly territorial (Smith 1987; Hardy et al. 1991) and are probably philopatric (Smith \& Hammill 1981); this strongly indicates that prime breeding habitat is utilised to a maximum by the most experienced and dominant breeding ringed seals in Svalbard. This type of habitat totals about $273 \mathrm{~km}^{2}$ for the whole of Svalbard and represents only about $1.4 \%$ of the entire fast ice (Table 4) available to ringed seals in this region.

A recalculation of the density of ringed seal lairs in Kongsfjorden in 1984, which excludes the flat ice area of Dyrevika, gives a density of $5.46 \mathrm{~km}^{-2}$ for the glacier front areas of the fjord systems, which is close to mean densities found in the area of Barrow Strait in the Canadian High Arctic (Hammill \& Smith 1989). Hammill \& Smith (1991) estimated that each adult female ringed seal maintained 2.1 birth lairs. Using this factor, a preliminary estimate of 710 pups could be produced annually in the glacier front areas of Svalbard. For the flat fjord ice areas we have related the number of adult females to the number of breathing holes. We have chosen the inner part of Sassenfjorden (Stratum II in Lydersen \& Ryg 1991) as a representative stable, flat ice area. The only other alternative was Van Mijenfjorden which is atypical compared to other western Spitsbergen fjords in that it doesn't end in an active glacier front. The Sassenfjorden area had a breathing hole density of $4.42 \mathrm{~km}^{-2}$ and $25 \%$ of the holes were considered belonging to males based on their characteristic smell. Considering all other breathing holes belonging to adult females, and using a breathing hole to seal ratio of 3.4 (Hammill \& Smith 1991), an adult female density in the flat fjord ice areas in the breeding period was estimated to $0.98 \mathrm{~km}^{-2}$. This gives an estimate of 18,915 pups born annually in the flat fjord ice areas, and a total of 19,625 pups born annually in the whole of Svalbard's fast ice areas.

These broad extrapolations should be regarded only as a first approximation of ringed seal production in Svalbard. The NOAA database which we examined gave no indication of the appearance 
or quality of fast ice in the areas of Nordaustlandet (Area 3) which might in fact be one of the more productive regions for ringed seals because of the many small islands anchoring a large area of stable ice. Similarly the large expanse of ice in Hinlopen Stretet (Area 4) and Storfjorden (Area 5) must be looked at in more detail before assigning densities of breathing holes and birth lairs. It is especially important to obtain an indication of the surface topography of the ice, such as the frequency of pressure ridges and glacial debris providing opportunities for accumulation of snow.

The drifting pack ice does not appear to contribute significantly as a breeding habitat although this has never been properly investigated. Seals taken during several Pro Mare cruises in the offshore waters near Svalbard were of all age classes, but no significant concentration of breeding seals was encountered (T. G. Smith \& Morten Ryg, University of Oslo, pers. comm). In Canada a suggestion based on a very weak database has been made that there is a distinct breeding population in the pack ice of Baffin Bay (Finley et al. 1983). This was construed from a few helicopter surveys covering less than 0.002 of the area and a collection of 45 seals taken in the pack ice. Neither morphometric nor electrophoretic comparisons of the pack ice specimens to seals taken in the coastal fast ice provided convincing evidence for the existence of a separate ecotype in that study. The large variation in both electrophoretric and morphometric studies (Fedoseev. 1975) makes these types of comparisons nearly useless for ringed seals. Future research should consider the use of genetic markers (Hill 1987; Quinn \& White 1987) to investigate the possible existence of different sub-populations.

The marine waters adjacent to Svalbard are relatively productive. Offshore primary pro-

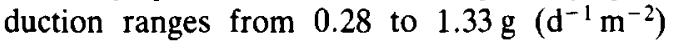
which is higher than the range for most Arctic waters (Subba Rao \& Platt 1984). The inner fjords also are quite high in secondary productivity as indicated by the active commercial shrimp fishery in the area. It is thus not likely that ringed seals are limited by food in the Svalbard area.

The large annual variation in total fast ice and an indicated high predation mortality, especially in the flat ice breeding habitat, signal a reason for concern about the conservation and management of ringed seals in Svalbard. The total extent of breeding habitat can, in some years, be reduced by as much as 30 to $40 \%$. Indications of extremely high pup predation in such years of low snow cover and restricted ice could result in almost total pup mortality in some areas of remaining breeding habitat.

The estimated $1700-2000$ bears in the Svalbard drift ice (Larsen 1986) suggests a major need for further refinement of ringed seal production estimates for the area. Polar bears might require approximately 50-73 seals per annum for growth and sustenance (Stirling 1974; Stirling \& Latour 1978). Without having the exact geographical or seasonal limits of their hunting territory, it is evident from the small annual production of about 19,500 ringed seals calculated in our study, that few bears could be supported on a sustained level from the Svalbard fast ice ecosystem. Further research on ringed seals should attempt to resolve this major discrepancy by evaluating the possibility of influx of ringed seals from adjacent geographic areas of fast ice and also by assessing the contribution of the pack-ice habitat. The use of satellite transmitters (Stewart et al. 1989) and genetic markers (Hill 1989; Quinn \& White 1987) will greatly facilitate that task. The importance of other seal species, first of all bearded seals (Erignathus barbartus), as food for polar bears should also be evaluated.

Acknowledgements. - This research was supported by the Norwegian Research Program for Marine Arctic Ecology (Pro Mare) through the Norsk Polarinstitutt (NP). We wish to thank $M$. Ryg and $\emptyset$. Sigde for help in the field and the NP staff at Ny Ålesund for logistic support. T. Vinje (NP) kindly provided access to the NOAA imagery and some discussion on aspects of the sea ice database. G. Kjarnli, Norsk Meterologiske Institutt, helped obtain data on sea ice distribution and snow depth measurements for Longyearbyen. N. Øritsland and I. Gjertz (NP) aided with reviews of the manuscript.

\section{References}

Fedoseev, G. A. 1975: Ecotypes of the ringed seal (Phoca hispida Schreber, 1775) and their reproductive capabilities. Pp. 156-160 in Ronald, K. \& Mansfield, A. W. (eds.): Biology of the seal. Rapp. P.-v. Réun. Cons. Int. Explor. Mer 169.

Finley, K. J., Miller G. W., Davis, R. A. \& Koski, W. R. 1983: A distinctive large breeding population of ringed seals ( $P$ hoca hispida) inhabiting the Baffin Bay pack ice. Arctic 36. 162173.

Hammill, M. O. \& Smith, T. G. 1989: Factors affecting the distribution and abundance of ringed seal structures in Barrow Strait, Northwest Territories. Can. J. Zool. 67, 22122219.

Hammill, M. O. \& Smith, T. G. 1991: The role of predation in 
the ecology of the ringed seal in Barrow Strait, Northwest Territories, Canada. Marine Mammal Sci. 7, 123-135.

Hardy, M. H., Roff, E. Smith, T. G. \& Ryg. M. 1991: Facial skin glands of ringed and grey seals, and their possible function as odoriferous organs. Can. J. Zool. 69, 189-200.

Hill, W. G. 1987: DNA fingerprints applied to animal and bird populations. Nature 327, 98-99.

Larsen, T. 1986: Population biology of the polar bear (Ursus maritimus) in the Svalbard area. Norsk Polarinst. Skr. 184. $55 \mathrm{pp}$.

Lebedev, V. V. 1938: Ice accreation in arctic rivers and seas as a function of negative air temperatures. Problemy Arktiki. 5-6.

Lunde, T. 1965: Ice conditions at Svalbard 1946-1963. Norsk Polarins. Árbok 1963.

Lydersen, C. \& Gjertz, I. 1984: Studies of the ringed seal (Phoca hispida Schreber 1775) in its breeding habitat in Kongsfjorden. Svalbard. Norsk. Polarinst. Rapportserie 19. $46 \mathrm{pp}$.

Lydersen. C. \& Gjertz, I. 1986: Studies of the ringed seal (Phoca hispida Schreber 1775) in its breeding habitat in Kongsfjorden. Svalbard. Polar Res. 4, 57-63.

Lydersen,C. \& Gjertz, I. 1987: Population parameters of ringed seals (Phoca hispida Schreber. 1775) in the Svalbard area. Can. J. Zool. 65. 1021-1027.

Lydersen, C. \& Ryg, M. S. 1991: Evaluating breeding habitat and populations of ringed seals (Phoca hispida) in Svalbard fjords. Polar Rec. 27, 223-228.

Lydersen, C. \& Smith, T. G. 1989: Avian predation on ringed seal, Phoca hispida, pups. Polar Biol. 9, 489-490.

Lydersen, C., Jensen, P. M. \& Lydersen, E. 1987: Studies of the ringed seal population in the Van Mijen fjord, Svalbard, in the breeding period 1986. Norsk Polarinst. Rapportserie $34,91-112$.

Lydersen. C., Jensen, P. M. \& Lydersen, E. 1990: A survey of the Van Mijen Fjord, Svalbard, as habitat for ringed seals, Phoca hispida. Holarctic Ecol. 13, 130-133.

Quinn, T. W. \& White, B. N. 1987: Analysis of DNA sequence variation. Pp. 163-198 in Cooke, F. \& Buckley, P. H. (eds.): Avian Genetics. Academic Press, London.

Smith, T. G. 1976: Predation of ringed seal pups (Phoca hispida) by the arctic fox (Alopex lagopus). Can. J. Zool. 54, 16101616.

Smith, T. G. 1980: Polar bear predation of ringed and bearded seals in the land-fast sea icc habitat. Con. J. Zool. 58. 22012209.
Smith, T. G. 1987: The ringed seal, Phoca hispida, of the Canadian Western Arctic. Can. Bull. Fish. Aquat. Sci. 216. $81 \mathrm{pp}$.

Smith. T. G. \& Hammill, M. O. 1981: Ecology of the ringed seal, Phoca hispida, in its fast ice breeding habitat. Can.J. Zool. 59, 966-981

Smith, T. G. \& Stirling, I. 1975: The breeding habitat of the ringed seal (Phoca hispida). The birth lair and associated structures. Can. J. Zool. 53, 1297-1305.

Smith, T. G. \& Stirling, I. 1978: Variation in the density of ringed seal. (Phoca hispida), birth lairs in the Amundsen Gulf, Northwest Territories. Can. J. Zool. 56, 1066-1071.

Smith, T. G., Hammill, M. O. \& Taugbøl, G. A. 1991: Review of the developmental, behavioural and physiological adap. tations of the ringed seal, Phoca hispida, to life in the arctic winter. Arctic 44, 129-131.

Steffensen, E. L. 1982: The climate at Norwegian Arctic Stations. Klima No. 5. 44 pp.

Stewart. B. S., Leatherwood, S. Yochem, P. \& Heide-Jorgensen, M. P. 1989: Harbour seal tracking and telemetry by satellite. Marine Mammal Sci. 5 (4) . 361-375.

Stirling. I. 1974: Midsummer observations on the behaviour of wild polar bears (Ursus maritimus). Can. J. Zool. 52, 11911198.

Stirling. I. and Archibald, W. R. 1977: Aspects of polar bear predation. J. Fish. Res. Bd. Can. 34, 1126-1129.

Stirling, I. \& Latour, P. 1978: Comparative hunting abilitics of polar bear cubs of different ages. Can. J. Zool. 56, 17681772 .

Stirling, I. \& McEwan, E. H. 1975: The caloric value of whole ringed seals ( $P$ hoca hispida) in relation to polar bears (Ursus maritimus) ecology and hunting behaviour. Can. J. Zool. 53 . 1021-1027

Subba Rao, D. V. \& Platt, T. 1984: Primary production of arctic waters. Polar Biol. 3, 191-201.

Taugbol, G. 1984: Ringed seal thermoregulation, energy balance and development in early life, a study on Pusa hispida in Kongsfjorden, Svalbard. Thesis, 1982. Zoofysiologisk Inst., Univ. Oslo, Norway. 102 pp. (Translation, Fish. Aquat. Sci. No. 5090 .)

Vinje, T. E. 1967-1982: Annual reports in Norsk Polarinstitutt Àrbok.

Vinje, T. E. 1985: The physical environment of the western Barents Sea. Drift, composition morphology and distribution of sea ice fields in the Barents Sea. Norsk Polarinst. Skr. 179. $26 \mathrm{pp}$. 